ISSN: 2146-3042

DOI: $10.25095 /$ mufad.536037

\title{
İşletme Sermayesi Yönetimi ve Karlılık İlişkisi: Doğrusal Olmayan İlişkinin BIST Kimya, Petrol, Kauçuk ve Plastik Ürünler Sektöründe Sınanması
}

\author{
Burcu DİNÇERGÖK*
}

\section{$\ddot{O Z Z E T}$}

İşletme sermayesi yönetimi ve karlılık ilişkisi literatürde geniş çapta araştırılmış olan bir konu olmasına rağmen, söz konusu ilişki çoğunlukla doğrusal modellerle test edilmiştir. Oysa ki işletme sermayesi unsurlarından alacaklar, stoklar, ticari borçlar ve karlılık arasındaki ilişki doğrusal olmayabilir. Özellikle düşük seviyelerdeki alacak, stok ve ticari borçların arttırılması karlılığı arttırırken, belirli bir düzeyin üzerindeki unsurların arttırılması karlılığa zarar verebilir. Bu çalışmanın amacı, 2005-2016 yılları arasında Borsa Istanbul Kimya, Petrol, Kauçuk ve Plastik Ürünler Sektöründe faaliyet gösteren işletmeler için işletme sermayesi yönetimi ve karlılık ilişkisini doğrusal olmayan modelle tespit etmektir. Uygulanan Genelleştirilmiş Momentler Yöntemi (GMM) yönteminin sonuçları özellikle alacaklar, ticari borçlar ve karlılık arasında doğrusal olmayan, konkav bir ilişkinin varlığına kanıt sunmaktadır. Stoklar için elde edilen sonuçlar ise teorik beklenti ile uyumlu değildir.

Anahtar Kelimeler: İşletme Sermayesi Yönetimi, Karlılık, GMM, Doğrusal Olmayan İlişki.

JEL Sınıflandırması: G30, G39

The Relationship Between Working Capital Management and Profitability: Testing the Nonlinear Relationship in Borsa Istanbul Chemical, Petrolium, Rubber and Plastic Products Sector

\section{ABSTRACT}

The relationship between working capital management and profitability is extensively investigated in the literature; much of this literature tests this relationship using linear models. However, the relationship between the components of working capital, namely; receivables, inventories, trade payables and profitability, may not be linear. At low levels of receivables, inventories and trade payables, increasing the amount of working capital components may increase profitability up to a point, but above that point additional increases may harm profitability. The aim of this study is to test this expected nonlinear relationship using data on the firms quoted to Istanbul Stock Exchange Chemical, Petrolium, Rubber and Plastic Products Sector over the 2005-2016 period. Results of the Generalized Method of Moments (GMM) analysis indicates that there is a significant nonlinear and concave relation between receivables, trade payables and profitability ratios. As for the inventories the results are not inline with the theoric expectations.

Keywords: Working capital management, profitability, GMM, nonlinear relation.

Jel Classification: G30, G39

Makale Gönderim Tarihi: 06.07.2018

Makale Kabul Tarihi: 21.09.2018

\footnotetext{
* Dr. Öğr. Üyesi, Atılım Üniversitesi, İşletme Fakültesi, burcu.dincergok@atilim.edu.tr, ORCID ID: 0000-0002$7050-8163$.
} 


\section{GİRIŞ}

Genel olarak işletme sermayesi, işletme faaliyetlerinin sürdürülmesi amacı ile firmanın kısa sürede paraya çevrilebilecek değerlere yapmış olduğu yatırım tutarını ifade etmektedir (Aksoy ve Yalçıner, 2005: 1). Tipik bir üretim işletmesinde dönen varlıklara yapılan yatırım tutarı toplam varlıkların yarısını aşmaktadır (Van Horne,2008: 206). İşletmenin ihtiyacı olan işletme sermayesi düzeyinin belirlenmesi, belirlenen işletme sermayesi miktarının işletme sermayesi unsurları arasında ne şekilde dağıtılacağının tespit edilmesi ve işletme sermayesi ihtiyacının ne şekilde finanse edileceğine karar verilmesi, finans yöneticilerinin zamanlarının büyük bir kısmını alan ve günlük bazda takibi gerektiren önemli konulardır (Sayılgan, 2017: 197-198). Söz konusu konularda alınan kararlar işletme sermayesi politikaları olarak adlandırılmaktadır (Brigham ve Houston, 2002: 690).

İşletme sermayesi politikaları firmaların likiditesi, riski ve karlılığı üzerinde ve dolayısı ile firma değeri üzerinde önemli etkiye sahiptir. Finansmanda yüksek getiri ve yüksek riske sahip olan işletme sermayesi yatırım politikaları "saldırgan politika" olarak adlandırılırken, düşük getiri ve riske sahip olan politikalar "ihtiyatlı politika" olarak adlandırılmaktadır. Saldırgan politikada, diğer firmalarla kıyaslandığında, belirli bir satış ya da faaliyet düzeyi için işletme sermayesi unsurlarına daha az tutarda yatırım yapılmaktadır. Örneğin, kasada daha az para bulundurulmakta, alacaklara ve stoklara daha az para bağlanmaktadır. Bunun tam tersi olan ihtiyatlı politikada ise yine belirli bir satış ya da faaliyet düzeyi için, işletme sermayesi unsurlarına -diğer firmalarla kıyaslandığında- daha fazla tutarda yatırım yapılmaktadır.

Saldırgan ve ihtiyatlı politikaların tanımları değerlendirildiğinde, stoklara ve ticari alacaklara yapılan yatırım tutarı ve karlılık arasında negatif ve doğrusal bir ilişki beklenebilmektedir. Stoklara daha az yatırım yapılması ve etkin bir stok yönetimi firmaları stok bulundurmanın gerektirdiği maliyetlerden kurtaracaktır. Alacaklara daha az para bağlanması ve alacak tahsil süresinin kısalı̆̆ı alacakların zamanında tahsil edildiğinin göstergesi olup, şüpheli alacaklara ilişkin maliyetlerin ortadan kalkması yönünde olumlu yönde katkı sağlayacaktır. Stoklara ve alacaklara daha az para bağlanması hem de bu unsurlara bağlanacak paranın daha karlı olan yatırımlarda değerlendirilmesini sağlayabilecek, hem de bu varlıklar için gereken fonlama maliyetini azaltacaktır. Bunun sonucunda karlılık artacaktır. Ticari borçlar açısından bakıldığında ise beklenen ilişki pozitif yönlü ve doğrusal bir ilişkidir. Diğer kaynaklara göre daha düşük maliyeti olan ticari borçların artması karlılı̆̆ arttıracaktır. Nitekim "Literatür Taraması" bölümünde detayları ile açıklanacağı üzere, bu konuda yapılmış olan pek çok ulusal ve uluslararası çalışmada ilişkinin varlığı doğrusal modellerle sinanmıştır.

Ancak işletme sermayesindeki artışın karlılık üzerindeki etkisi, başlangıçtaki işletme sermayesi düzeyine göre farklıllk gösterebilir. Örneğin düşük hatta yetersiz düzeyde stok bulunduran bir firmanın stoklarını arttırması karlar üzerinde pozitif etki yaratırken, stokları yüksek düzeyde olan bir firmanın stoklara ekstra yatırım yapması karlılığı azaltabilir. Dolayısı ile stoklara yapılacak yatırım ve karlılık arasında beklenen ilişki doğrusal değil konkav (ters u) bir ilişkidir. Bu durum alacaklar ve ticari borçlar için de geçerlidir. 
$\mathrm{Bu}$ çalışmanın amacı karlılık ve işletme sermayesi unsurları arasındaki ilişkinin doğrusal olup olmadığının ortaya konulmasıdır. Literatürde işletme sermayesi yönetimi ve karlılık ilişkisini doğrusal olmayan modellerle ele alan az sayıda çalışma bulunmaktadır. Yazarın bilgisi dahilinde Türkiye'de işletme sermayesi unsurları ve karlılık ilişkisini doğrusal olmayan modelle ele alan başka bir çalışma bulunmamaktadır ${ }^{1}$.

Çalışma 2005-2016 yıllarında Borsa İstanbul'a kayıtlı Kimya, Petrol, Kauçuk ve Plastik Ürünler sektöründe faaliyet gösteren firmaları kapsamaktadır. Merkez Bankası Sektör Bilançoları verilerine bakıldığında, Kimya ve Kimyasal Ürünlerin İmalatı sektöründe dönen varlıkların toplam aktiflerin yaklaşık \%70'i civarında olduğu görülmektedir (TCMB, 2017). Hem söz konusu oranın büyüklügüü, hem de BIST' deki Kimya, Petrol, Kauçuk ve Plastik Ürünler sektöründeki firmalarda bu şekilde bir analizin yapılmamış olmaması çalışmanın önemini arttırmaktadır.

Çalışmada dinamik panel veri yöntemlerinden tek aşamalı fark Genelleştirilmiş Momentler Yöntemi (GMM) kullanılmıştır. Çalışma sonuçları alacak tahsil süresi, ticari borç ödeme süresi ve karlılık arasında konkav (ters-u) şeklinde bir ilişki olduğunu ortaya koymaktadır. Stokta bekleme süresi için bulunan sonuçlar ise beklentinin aksine konveks bir ilişkinin varlığına işaret etmektedir.

Çalışmada sırasıyla işletme sermayesi unsurları ve karlılık ilişkisi, literatür taraması, veri ve yöntem, bulgular ve sonuç bölümlerine yer verilecektir.

\section{2. İŞLETME SERMAYESİ UNSURLARI VE KARLILIK İLIŞKİSI}

Giriş bölümünde de belirtildiği üzere işletme sermayesi yönetimi ve karlılık arasında önemli bir ilişki bulunmaktadır. Bu konuda pek çok çalışmada stoklar, alacaklar, ticari borçlar ve karlılık arasında istatistiki açıdan anlamlı ilişkiler olduğu ortaya konulmuştur. Bu çalışmada beklenen işletme sermayesi unsurları ve karlılık arasındaki ilişkinin konkav bir ilişki olduğudur.

Stokları düşük düzeylerde olan bir firma üretimde kesintiler yaşayabilir, stokların yetersizliği sebebi ile müşteri taleplerini karşılayamayabilir ve karlı satış firsatlarını kaçırabilir. Müşteri siparişlerinin yerine getirilmemesi sebebi ile- sözleşmelerde belirtilmek sureti ile- tazminat ödemek zorunda kalabilir ve müşteri güvenini kaybedebilir. Ayrıca stokları düşük düzeyde olan firmalar miktar iskontolarından faydalanamayabilirler (Akgüç, 1998: 292). Dolayısı ile bu durumdaki firmalar için stoklara yapılacak olan yatırım karlılığ arttırıcı etki yaratabilir.

Alacaklar açısından ele alındığında da, rakip firmalar vadeli satış politikası izlerken, herhangi bir firmanın bu uygulamanın dışında kalarak alacak düzeyini düşük tutması, dışarıda kalan firma için satışlarını azaltıcı bir etki yaratabilecektir. Vadeli satışlar, müşterilerin ödeme yapmadan önce aldıkları ürünü kontrol edebilmelerini sağlayarak, alıcı ve satıc1 arasındaki asimetrik bilgi problemini azaltmaktadır (Deelof ve Jegers, 1996: 33, BanosCaberollo vd. 2012: 519). Bunun yanında düşük talep durumlarında talebi canlandırmak için

\footnotetext{
${ }^{1}$ Aytürk ve Yanık (2015) nakit döngüsü ve karlılık arasındaki ilişsiyi doğrusal olmayan modelle analiz etmişlerdir.
} 
vadeli satışlar bir araç olarak kullanılmaktadır (Emery, 1987: 209). Ayrıca vadeli satışlar, müşterilerin hangi ürünü seçeceği konusunda kararsızlık yaşadığı durumlarda, ürünleri birbirinden farklılaştırmayı sağlamaktadır. Vadeli satışların bir diğer faydası da müşterilerle uzun dönemli ilişkilerin kurulmasını sağlamasından kaynaklanmaktadır (Banos-Caberollo vd. 2012: 519). Tüm bu özellikleri dikkate alındığında, özellikle alacak düzeyi düşük olan firmalar için alacaklara yapılacak yatırımın satışları arttırması ve karlılığı arttırması beklenebilir.

Ticari borçlar açısından düşünüldüğünde ise; kredili olarak mal alınması, satıcının alıcı firmaya kredi kullandırmasını ifade etmektedir. Böylece alıcı firmanın sermaye ihtiyacı azalacaktır. Satıcı kredilerinin vadesi ticarete konu olan malın nakde dönüşüm süresinin uzunluğu, alıcı ve satıcının mali durumu gibi faktörlerden etkilenmektedir (Aksoy ve Yalçıner, 2005: 325). Ticari borçlar, satıcının alıcıya erken ödemede tanıyacağı iskonto oranına bağlı olarak daha ucuz ve daha esnek bir fon kaynağı olabilmektedir (Deelof, 2003: 574). Bu nedenle belirli bir seviyeye kadar ticari borçların artması işletme karlılığını arttırıcı bir etki yaratabilecektir.

İşletme sermayesi unsurlarından stoklara aşırı yatırım yapıldığında stoklara ilişkin depolama, izleme, sigorta, vergi vs. maliyetleri de artacaktır. Stokta bekleme süresinin uzaması stoklara ilişkin yıpranma, bozulma vs. ilişkin maliyetleri de arttırabilmektedir. Ayrıca stoklara bağlanan paranın firsat maliyeti de yükselecektir (Ross,2008). Bunun dişında alacak tahsil süresinin uzaması alacakları tahsil edememeye ilişkin riski ve bunlarla ilgili maliyetleri arttıracaktır. Alacak ve stoklara yapılacak aşırı yatırım bu unsurlara ilişkin fonlama maliyetlerini de arttıracaktır. İşletme sermayesi unsurlarından stok ve alacaklara yapılacak aşırı yatırım firmaları iflas riski ve bunun getirdiği faaliyetlerdeki aksama ve duraksama riski ile karşı karşıya bırakabilmektedir (Aktaş vd. 2015:99). Ticari borç ödeme süresinin uzaması da firmanın tedarikçileri ile ilişkilerinin bozulmasına, sürekli mal temin edilen tedarikçilerden mal temin edilememesi gibi problemlere yol açacaktır. Ticari borç ödeme süresinin uzaması firmanın kullandığg 1 dış kaynakların maliyetini de yükseltebilecektir.

Tüm bunlardan çıkan sonuç alacaklara ve stoklara yapılacak ekstra yatırımların belirli bir noktaya kadar karlılığ $\operatorname{arttırdığı~ancak~bu~noktanın~üzerinde~ise~yapılacak~ekstra~yatırımın~}$ karlılığ 1 azalttığı yönündedir. Benzer şekilde ticari borç kullanımı da bir noktaya kadar karlılığı arttıracak ancak o noktanın üzerinde karlılığı azaltacaktır.

\section{LITERATÜR TARAMASI}

İşletme sermayesi yönetimi ve karlılık arasındaki çalışmalar incelendiğinde çalışmaların büyük ölçüde doğrusal modeller kullanılarak yapılmış olduğu görülmektedir.

Deelof (2003) sabit etkiler ve en küçük kareler yöntemlerini kullanarak, işletme sermayesi yönetiminin Belçika'daki firmaların karlılı̆̆ı üzerindeki etkisini analiz etmiştir. 1992-1996 yılları arasını kapsayan çalışmada; alacak tahsil süresi, stokta bekleme süresi ve ticari borç ödeme süresi ile karlılık arasında negatif yönlü bir ilişki olduğu tespit edilmiştir.

İran'daki ilaç ve çimento endüstrilerinde 2006-2009 yıllarında faaliyet gösteren firmalar üzerinde yapmış oldukları çoklu regresyon analizlerinde Vahid vd. (2012) alacak tahsil süresi, stokta bekleme süresi ve borç ödeme sürelerindeki artışın ve net ticaret 
döngüsündeki artışın karlılığı azalttığını ancak nakit döngüsü ve karlılık arasındaki ilişkinin istatistiki açıdan anlamlı olmadığını ifade etmişlerdir.

Singhania vd. (2014) Hindistan'da 2005-2012 yılları arasında Bombay Borsasına kayıtlı imalat sektörü firmalarında, işletme sermayesi yönetimi ve karlılık ilişkisini, makroekonomik faktörleri de dikkate alarak araştırmışlardır. Çalışmada sabit etkiler modeli kullanılmıştır. Çalışma sonucunda nakit döngüsünün karlılığ 1 azalttığı, alacak tahsil süresini azaltmanın ve borç ödeme süresini arttırmanın karlılığ 1 arttırdığ 1 ifade edilmiştir.

Türkiye'deki çalışmalara bakıldığında Öz ve Güngör (2007), 1992-2005 döneminde Borsa İstanbul'a kayıtlı imalat sektörü firmaları üzerinde yapmış oldukları panel veri analizinde, alacak devir hızı, borç devir hızı, stok devir hızı ve net ticaret süresinin karlılı̆̆ negatif yönde etkilediği sonucuna ulaşmışlardır. Şamiloğlu ve Demirgüneş (2008) Borsa İstanbul'da 1998-2007 döneminde faaliyet gösteren imalat sektörü firmaları üzerinde yapmış oldukları analizde alacak tahsil süresi ve stokta bekleme süresinin ve kaldıraç oranlarının karlılığı negatif yönde etkilediğini, firma büyüme oranının ise karlılık üzerinde olumlu etkiye sahip olduğunu ifade etmişlerdir. Nakit döngü süresi, büyüklük ve uzun vadeli finansal varlıklar ile karlılık arasında istatistiki yönden anlamlı bir ilişki ise tespit edilememiştir. Akbulut (2011) regresyon ve ANOVA yöntemini kullanarak yapmış olduğu ve 2000-2008 dönemini kapsayan çalışmasında, Borsa İstanbul imalat sektöründeki firmalarda nakit döngüsü ve karlılık arasında negatif ilişki olduğunu ortaya koymuştur. Coşkun ve Kök (2011) dinamik panel veri analizi kullanarak yapmış oldukları çalışmalarında, 1991-2005 döneminde Borsa İstanbul imalat sektöründe yer alan firmaların nakit döngüleri, alacak tahsil süreleri, stokta bekleme süreleri, borç ödeme süreleri ve karlılıkları arasındaki ilişkileri analiz etmişlerdir. Elde edilen sonuçlar söz konusu firmaların nakit döngüleri, alacak tahsil süreleri, stokta bekleme süreleri ve karlılıkları arasında negatif ilişki; borç ödeme süresi ve karlılık arasında ise pozitif ilişki olduğunu ortaya koymaktadır. Çakır ve Küçükkaplan (2012) işletme sermayesi unsurlarının karlılığa olan etkisini 2000-2009 dönemi için panel veri yöntemini kullanarak analiz etmişler ve asit test oranı, stok devir hızı ve aktif devir hızının karlılığa etkisinin pozitif olduğunu, cari oran ve kaldıraç oranlarının karlılık üzerindeki etkisinin negatif olduğunu ifade etmişlerdir. Keskin ve Gökalp (2016), 2009-2013 döneminde Borsa İstanbul Gıda ve İçecek Sektöründe faaliyet gösteren firmaları panel veri analizi ile analiz ettiği çalışmasında sadece alacak tahsil süresi ve cari oranın karlılık üzerinde negatif ve anlamlı etkisi olduğu sonucuna ulaşmışlardır.

Banos-Caberollo vd. (2012), Aktaş (2015) ve Aytürk ve Yanık (2015)'ın çalışmaları ise nakit döngüsü ve karlılık arasındaki ilişkiyi doğrusal olmayan modellerle test etmişlerdir.

Yazarın bilgisi dahilinde işletme sermayesi yönetimi ve karlılık arasında doğrusal olmayan ilişkiyi test eden öncü çalışma Banos-Caberollo vd. (2012)'ya aittir. İspanya'da küçük ve orta büyüklükteki firmaları Genelleştirilmiş Momentler Yöntemi (Generalized method of moments-GMM) yöntemi ile analiz ettikleri çalışmalarında, Banos-Caberollo vd. (2012) nakit döngü süresi ve karlılık arasında doğrusal olmayan ilişki tespit etmişlerdir.

Aktaş vd. (2015) işletme sermayesi yönetiminin hisse fiyatları ve faaliyet performansı üzerindeki etkilerini Amerika'daki firmalar üzerinde 1982-2011 yılı verilerini kullanarak test etmişlerdir. Çalışma sonucunda firmaların optimal bir işletme sermayesi düzeyine sahip oldukları ve bu düzeyden sapmanın firmanın hisse senedi fiyatına ve faaliyet performansına 
zarar verdiği ifade edilmiştir. Yazarlar ayrıca işletme sermayesi yönetiminin işletme performansını yatırım kanalı ile arttırdı̆̆ını ortaya koymuşlardır.

Aytürk ve Yanık (2015) 2009-2013 dönemi boyunca Türkiye'deki Küçük ve orta büyüklükteki firmaların (KOBİ) verilerini kullanarak yapmış oldukları çalışmalarında KOBI'lerde nakit döngüsü ve karlılık arasında doğrusal olmayan ilişkiye dair bir kanıt bulamamışlar ancak nakit döngüsü ve karlılık arasında negatif ilişki olduğunu ifade etmişlerdir.

Nadiri (1969), Emery (1984) ticari alacaklar için; Ouyeng ve diğerleri (2005) ve Chung (2010) stoklar için; Nadiri (1969) ticari borçlar için optimal bir seviye olduğunu ortaya koymuştur. Yine Garcia-Teruel ve Martinez-Solano (2010a) firmaların hedef bir ticari borç oranına ve Garcia- Teruel ve Martinez-Solano (2010b) firmaların hedef bir ticari alacak oranına sahip olduklarını ifade etmişlerdir. Ancak yazarın bilgisi dahilinde işletme sermayesi unsurları ve karlılık arasındaki ilişkiyi doğrusal olmayan modelle analiz eden ve bu çalışmadaki modele benzer bir modeli olan tek çalışma Pais ve Gama (2015)'ya aittir. Pais ve Gama (2015) işletme sermayesi yönetimi ve karlılık arasındaki ilişkiyi, Portekiz'deki küçük ve orta ölçekteki firmalara ait olan, 2002-2009 dönemine ilişkin veriler ile analiz etmişlerdir. Yöntem olarak panel veri analizinin kullanıldığı çalışmada ilişki hem doğrusal hem de doğrusal olmayan modellerle test edilmiştir. Doğrusal modele göre yapılan analiz sonucunda, alacak tahsil süresi, stokta bekleme süresi ve borç ödeme süresindeki artışın karlılıkta azalmaya neden olduğu tespit edilmiştir. Doğrusal olmayan modellere göre yapılan analiz sonucu ise teorik beklenti ile uyumlu değildir. Alacaklar, stoklar, ticari borçlar, nakit döngü süresi ve karlılık arasında konveks bir ilişki olduğu tespit edilmiştir.

Literatür taramasında da görüldüğ̈ gibi işletme sermayesi yönetimi ve karlılık arasındaki doğrusal ilişkiyi test eden pek çok çalışma bulunmasına rağmen, doğrusal olmayan ilişkiyi test eden çalışma sayısı son derece azdır. Ayrıca literatürde doğrusal olmayan ilişkinin varlığı çoğunlukla sadece nakit döngüsü dikkate alınarak test edilmeye çalışılmıştır. Nakit döngüsü işletme sermayesi yönetiminin etkinliğini ölçen önemli bir gösterge olmasına rağmen, matematiksel olarak stokta bekleme süresi, alacak tahsil süresinin toplamından, borç ödeme süresi düşülerek elde edilmektedir. $\mathrm{Bu}$ nedenle nakit döngüsünde hangi işletme sermayesi unsurunun artışı ya da azalışının elde edilen sonuca sebep olduğu ise net olarak ortaya konulamamaktadır. Bu sebeple, bu çalışmada diğer çalışmalardan farklı olarak işletme sermayesi unsurları olan alacaklar, stoklar ve ticari borçlar ve karlılık arasındaki doğrusal olmayan ilişki test edilmektedir.

\section{VERİ VE YÖNTEM}

Çalışmada son dönemlerde panel veriye dayalı analizlerinde sıklıkla kullanılan dinamik panel veri yöntemi kullanılmıştır. Dinamik panel veri yönteminin statik panel veri yöntemlerinden fark1, dinamik panel veri yönteminin içerisinde gecikmeli değişkenlerin bulunmasından ileri gelmektedir (Tatoğlu, 2013: 85). Dinamik panel veri analizlerinde en çok kullanılan yöntemlerden biri Arellano ve Bond (1991) tarafından önerilen "Genelleştirilmiş Momentler Yöntemi”' (GMM)'dir.

Arellano ve Bond (1991) tahmincileri, kısa zaman boyutu ve geniş yatay kesit boyutunun var olduğu verilerde, kesitlerin heterojen olduğu durumlarda, bağımlı değişkenin 
cari değerinin geçmiş değerlerden etkilendiği durumlarda, bağımsız değişkenlerin kati bir şekilde dışsal olmadığı durumlarda uygun olarak kullanılabilmektedir (Roodman, 2009: 86).

Çalışma, 2005-2016 yılları arasındaki 12 yıllık bir dönemi kapsamaktadır. Borsa İstanbul'a kayıtlı Kimya, Petrol, Kauçuk ve Plastik ürünler sektöründe söz konusu dönemde faaliyet gösteren 25 firmaya ilişkin finansal veriler kullanılarak analiz gerçekleştirilmiştir. Elde edilen veri seti 202 gözlemi kapsayan dengesiz bir panel veri setidir. Firmalar heterojendir ve firma karlılığını etkileyen ve ölçümlenemeyen firmaya özgü faktörler bulunmaktadır. Ayrıca, cari dönemin karlılık oranları, geçmiş dönemlerdeki karlılık oranlarından etkilenebilmektedir (Banos-Cabarello vd., 2012: 523, Aytürk ve Yanık, 2015: 164, Coşkun ve Kök, 2011: 82). Bu nedenle oluşturulan modellere karlılık oranlarının geçmiş değerleri de bağımsız değişken olarak konulmuştur ve bu şekilde otoregresif dinamik bir panel yapı elde edilmiştir.

Deelof (2003) işletme sermayesi unsurları ve karlılık arasındaki ilişkiyi ele aldığı çalışmasında elde etmiş olduğu sonuçların içsellik probleminden etkilenebileceğini ifade etmiş ancak sorunun çözümüne ilişkin bir öneride bulunmamıştır. Deelof (2003)'e göre alacak tahsil süresi, stokta bekleme süresi ve borç ödeme süresi karlılığı etkileyebileceği gibi karlılık değişkeni de söz konusu değişkenleri etkileyebilir. Örneğin karlılık ve alacak tahsil süresi arasında bulunacak olan negatif yönlü bir ilişki düşük karlılığa sahip olan firmaların, satışlarını arttırmak için müşterilerine uzun vadeler tanımasından da kaynaklanabilir. Benzer bir şekilde satışları ve karlılıkları azalan bir firma stoklarının satılmadığı sonucu ile karşı karşıya kalabilir. Yine karlılık ve borç ödeme süresi arasında bulunacak negatif yönlü bir ilişki düşük karlılığa sahip olan firmaların borç ödeme sürelerini uzatmak istemesinden kaynaklanabilir (Deelof, 2003: 580). Bu çalışmada alacak tahsil süresi, stokta bekleme süresi, borç ödeme süresi değişkenleri ve söz konusu üç değişkenin kareleri içsel değişken olarak analize dahil edilmiştir. Ayrıca, Garcia-Teruel ve Martinez-Solano (2010a) tarafindan da ifade edildiği üzere firmaya özgü finansal değişkenleri dişsal olarak kabul etmek uygun olmayacağ 1 için firmaya özgü kontrol değişkenleri de endojen olarak analize tabi tutulmuştur.

Hata terimleri ile açıklayıcı değişkenler arasındaki ilişkinin varlığına dayanan içsellik probleminin çözümü için dinamik panel modellerinin birinci farkı alınarak kesite özgü heterojenlik problemi ortadan kaldırılmaktadır. Ancak; hata terimi ve gecikmeli bağımlı değişken arasındaki ilişkinin önüne geçilmesi için Arellano ve Bond (1991) araç değişken matrisi ile farkı alınmış modellerin dönüştürülmesini ve bu dönüştürülmüş modelin genelleştirilmiş en küçük kareler yöntemi ile tahmin edilmesini önermişlerdir (Tatoğlu, 2013: 90). Bu çalışmada tek aşamalı fark GMM yöntemi kullanılarak çalışma modelleri tahmin edilmiştir.

Alacak tahsil süresinin, stokta bekleme süresinin ve ticari borç ödeme süresinin karlılık üzerindeki etkilerinin test edilmesi amacı ile Model 1 oluşturulmuştur.

$$
\begin{aligned}
& K A R_{k, i, t}=\beta_{0}+\beta_{1} K A R_{i, t-1}+\beta_{2} A L_{i, t}+\beta_{2} A L_{i, t}^{2}+\beta_{4} S T_{i, t}+\beta_{5} S T^{2}{ }_{i, t}+\beta_{6} T B_{i, t}+\beta_{7} T B^{2}{ }_{i, t}+\beta_{8} F B_{i, t}+ \\
& B_{9} B Y_{i, t}+\beta_{10} K A L_{i, t}+\beta_{11} D V_{i i}+\beta_{12} F A i Z_{i}+\beta_{13} E N F_{i}+\eta_{i_{i}}+\varepsilon_{i, t}(\text { Model 1) }
\end{aligned}
$$

\footnotetext{
${ }^{2}$ Model ayrıca sektör ortalamalarına göre düzeltilmiş değerler kullanılarak ve alternatif bir kar oranı olan varlık karlılığı oranı kullanılarak da tahmin edilmiştir. İstenildiğ takdirde sonuçlar yazar tarafından temin edilebilir.
} 
Model 1'de görülen karlılık değişkeni olarak iki değişen kullanılmıştır. $K_{A R_{1} i_{1 / t}}$ değişkeni i firmasının $\mathrm{t}$ dönemindeki faaliyet karının aynı dönemdeki toplam varlıklara bölünmesi ile elde edilmiştir. $K A R_{1_{1}, i, t-1}$ değişkeni ise $K A R_{1_{1, i}, t}$ değişkeninin gecikmeli değerini ifade etmektedir. $K A R_{2, i, t}$ değişkeni ise i. firmasının t dönemindeki faiz ve vergi öncesi karının toplam varlıklara bölünmesi ile elde edilmiştir. $K A R_{2, i, t-1}$ değişkeni ise $K A R_{2_{m}, i, t}$ değişkeninin gecikmeli değerini ifade etmektedir. $A L_{i, t}$ alacak tahsil süresini ifade etmektedir ${ }^{3}$ ve i firmasına ait t yılındaki alacakların, satışlara bölünmesi ve bulunan rakamın 365 ile çarpılması ile elde edilmiştir. Alacak tahsil süresi ve karlılık arasındaki ilişkinin doğrusal olup olmadığının tespiti için $A L^{2}{ }_{i, t}$ yani alacak tahsil süresinin karesi modele eklenmiştir. $S T_{i, t}$ değişkeni de stokta bekleme süresini ifade etmektedir ve i firmasına ait t yılındaki stokların satışların maliyetine bölünmesi ile bulunan sonucun 365 ile çarpılması sonucunda elde edilmiştir. $S T^{2}{ }_{i, t}$ stokta bekleme süresinin karesidir ve stokta bekleme süresi ve karlılık arasındaki ilişkinin doğrusal olup olmadığının test edilmesi için modele eklenmiştir. $T B_{i, t}$ ticari borç ödeme süresini göstermektedir. İ firmasının ticari borçlarının satışların maliyetine bölünmesi ile elde edilen rakamın 365 ile çarpımı sonucu elde edilmiştir. $T B^{2}{ }_{i, t}$ ticari borç ödeme süresinin karesidir ve ticari borç ödeme süresi ile karlılık arasındaki doğrusal olmayan ilişkinin tespit edilebilmesi amacı ile modele eklenmiştir. Modeldeki kontrol değişkenlerden $F B_{i, t}$ i firmasının $\mathrm{t}$ dönemindeki firma büyüklüğünü ifade etmektedir ve satışların doğal logaritması alınarak hesaplanmaktadır. Çalışmadaki diğer bir kontrol değişkeni olan $B Y_{i, t}$ i firmasının bir önceki döneme göre satışlardaki büyüme oranını göstermektedir. $K A L_{i, t}$ ise i firmasının $\mathrm{t}$ dönemindeki finansal kaldıraç oranını gösteren diğer bir kontrol değişkenidir ve firmanın finansal borçlarının toplam varlıklara oranlanması ile elde edilmiştir. Modeldeki $D V_{i}$ dolar volatilitesini göstermektedir Türkiye Cumhuriyeti Merkez Bankasınca (TCMB) açıklanan haftalık dolar kurunun i yılına ait standart sapmasını ifade etmektedir. $F A I Z_{i}$ oranı aylik TL kredi faiz oranlarını i y1lındaki ortalamasını göstermektedir. $E N F_{i}$ ise yıllık tüketici fiyatları endeksinin (TÜFE) değişim oranını ifade etmektedir. Modeldeki firmalara ilişkin değişkenler Datastream veri tabanından elde edilmiştir. Makroekonomik değişkenler ise Türkiye Cumhuriyeti Merkez Bankası Elektronik Veri Dağıtım Sisteminden (EVDS) temin edilmiştir.

Model 1'de alacak tahsil süresi için tepe noktası matematiksel olarak $-\frac{\beta_{z}}{2 \beta_{s}}$ oranı ile, stokta bekleme süresi için tepe noktası $-\frac{\beta_{4}}{2 \beta_{5}}$ oranı ve ticari borç ödeme süresi için tepe noktası $-\frac{\beta_{6}}{2 \beta_{7}}$ oranı ile hesaplanmaktadır. İlişskinin alacaklar açısından konkav bir ilişki olduğunun ortaya konulabilmesi için $A L^{2}{ }_{i, t}$ değişkeninin katsayısının negatif olması, stoklar açısından konkav bir ilişkinin olduğunun ispatı için $S T_{i, t}^{2}$ değişkeninin katsayısının negatif olması ve ticari borçlar açısından konkav ilişkinin ortaya konulması için ise $T B^{2}{ }_{i, t}$ değişkeninin negatif olması gerekmektedir.

\footnotetext{
${ }^{3}$ Datastream veri tabanında alacaklar toplam rakam olarak yer almaktadır. Ancak analiz edilen firmalarda ticari alacaklar ve toplam alacaklar arasında farkın çok büyük olmaması sebebi ile alacaklar rakamı ticari alacak göstergesi olarak kullanılmıştır.
} 


\section{BULGULAR}

Çalışmada kullanılan değişkenlere ilişkin temel istatistikler tablosu Tablo 1'de görülmektedir. Değişkenler arasındaki korelasyon ilişkisi Tablo 2'de sunulmuştur.

Tablo 1. Temel İstatistikler

\begin{tabular}{llllll}
\hline Değişkenler & Ortalama & Medyan & Standart Sapma & 10. Yüzdelik & 90. Yüzdelik \\
\hline KAR1 & 0.064 & 0.065 & 0.074 & -0.008 & 0.14 \\
KAR2 & 0.086 & 0.084 & 0.086 & -0.10 & 0.17 \\
AL & 88.34 & 78.64 & 56.50 & 22.04 & 158.78 \\
AL $^{2}$ & 10985.84 & 6184.46 & 14263.38 & 485.95 & 25214.03 \\
ST & 100.06 & 70.66 & 98.37 & 31.38 & 189.40 \\
ST $^{2}$ & 19575.88 & 4862.38 & 61566.94 & 917.33 & 35873.42 \\
TB & 81.28 & 64.97 & 61.23 & 25.21 & 156.38 \\
TB & 10301.96 & 4193.83 & 22851.87 & 556.54 & 24455.57 \\
FB & 12.64 & 12.67 & 2.02 & 9.73 & 15.15 \\
BY & 0.15 & 0.12 & 0.23 & -0.08 & 0.42 \\
KAL & 0.21 & 0.19 & 0.15 & 0.004 & 0.42 \\
DV & 0.10 & 0.09 & 0.06 & 0.03 & 0.18 \\
FAİZ & 0.15 & 0.14 & 0.04 & 0.11 & 0.19 \\
ENF & 0.08 & 0.08 & 0.01 & 0.06 & 0.11 \\
\hline
\end{tabular}

Tablo 2. Korelasyon Matrisi

\begin{tabular}{|c|c|c|c|c|c|c|c|c|c|c|c|c|c|c|}
\hline Değişken & $\begin{array}{c}\text { KAR } \\
1\end{array}$ & $\begin{array}{c}\text { KAR } \\
2\end{array}$ & $\mathrm{AL}$ & $\mathrm{AL}^{2}$ & ST & $\mathrm{ST}^{2}$ & ТВ & $\mathrm{TB}^{2}$ & FB & BY & KAL & DV & FAİZ & ENF \\
\hline KAR1 & 1.00 & & & & & & & & & & & & & \\
\hline KAR2 & 0.83 & 1.00 & & & & & & & & & & & & \\
\hline $\mathrm{AL}$ & -0.07 & -0.06 & 1.00 & & & & & & & & & & & \\
\hline $\mathrm{AL}^{2}$ & -0.09 & 0.11 & 0.94 & 1.00 & & & & & & & & & & \\
\hline ST & -0.14 & -0.13 & 0.28 & 0.20 & 1.00 & & & & & & & & & \\
\hline $\mathrm{ST}^{2}$ & -0.10 & -0.11 & 0.14 & 0.10 & 0.90 & 1.00 & & & & & & & & \\
\hline TB & -0.02 & -0.17 & 0.20 & 0.19 & 0.56 & 0.50 & 1.00 & & & & & & & \\
\hline $\mathrm{TB}^{2}$ & -0.07 & -0.13 & 0.12 & 0.10 & 0.55 & 0.52 & 0.88 & 1.00 & & & & & & \\
\hline FB & 0.07 & 0.04 & -0.39 & -0.32 & -0.50 & -0.35 & -0.32 & -0.26 & 1.00 & & & & & \\
\hline BY & 0.32 & 0.26 & 0.05 & 0.08 & 0.10 & 0.03 & 0.15 & 0.15 & -0.13 & 1.00 & & & & \\
\hline KAL & -0.17 & -0.29 & 0.19 & 0.22 & 0.16 & 0.12 & 0.16 & 0.10 & -0.01 & 0.01 & 1.00 & & & \\
\hline DV & -0.00 & -0.00 & 0.09 & 0.08 & 0.03 & -0.04 & 0.03 & -0.05 & -0.00 & 0.03 & 0.11 & 1.00 & & \\
\hline FAİZ & -0.04 & -0.04 & -0.06 & -0.003 & -0.11 & -0.11 & -0.14 & -0.09 & 0.07 & -0.13 & -0.11 & 0.22 & 1.00 & \\
\hline ENF & 0.03 & -0.04 & -0.01 & -0.004 & -0.04 & -0.09 & -0.08 & -0.10 & 0.07 & 0.23 & -0.03 & 0.59 & 0.43 & 1.00 \\
\hline
\end{tabular}

Borsa İstanbul 'da 2005-2016 yılları arasında Kimya, Petrol, Kauçuk ve Plastik Ürünler sektöründe faaliyet gösteren firmaların ortalama faaliyet karlılı̆̆ $1 \% 6.4$ 'dür ortalama faiz ve vergi öncesi karı ise \%8.6'dır. Alacak tahsil süresi yaklaşık olarak ortalama 88.34 gün, stokta bekleme süresi ise 100.06 gündür. Ticari borç ödeme süresi ise ortalama olarak 81.28 gündür. Firmalar ortalama olarak \%15 civarında büyümektedir ve ortalama borçluluk oranları \%21'dir. Satışların doğal logaritması olarak hesaplanan firma büyüklüğü ortalama 
12.64'dür. 2005-2016 yılları arasında ortalama dolar volatilitesi \%10 olmuştur. Söz konusu dönemdeki faiz oran $1 \% 15$ ve enflasyon oranı da $\% 8$ 'dir.

Çalışma sonuçları Tablo 3'de ortaya konulmuştur. Bağımlı değişkenin faaliyet karlılı̆̆ olduğu analiz sonuçları Tablo 3'ün 1. sütununda, bağımlı değişkenin faiz ve vergi öncesi karlılık oranı olarak ele alındığı modelin analiz sonuçları tablonun 2 . sütununda raporlanmıştır. Fark GMM robust yöntemi ile tahmin edilen Model 1'in sonuçlarına bakıldığında bir önceki döneme ilişkin faaliyet karlılık oranının $\left(\mathbf{K A R}_{\mathbf{1 , i}, \mathrm{t}-\mathbf{1}}\right)$ bir sonraki dönem karlılığını $\mathbf{K A R}_{\mathbf{1}, \mathrm{i}, \mathrm{t}}$ pozitif yönde etkilediği ve elde edilen sonucun $\% 10$ düzeyinde anlamlı olduğu görülmektedir.

Model 1'den elde edilen sonuçlar alacak tahsil süresi ve faaliyet karlılığı arasındaki ilişkinin pozitif ve $\% 5$ düzeyinde anlamlı olduğunu ortaya koymaktadır. $\boldsymbol{A} \boldsymbol{L}_{i, t}$ ile ifade edilen alacak tahsil süresinin katsayısı 0.001 olarak hesaplanmıştır. Alacak tahsil süresinin karesi olan $\boldsymbol{A} \boldsymbol{L}^{2}{ }_{i, t}$ değişkenin katsayısı negatif (- (4.64e-06)). Bulunan sonuçlar istatistiki açıdan anlamlıdır. Elde edilen bu sonuç alacak tahsil süresi ve faaliyet karlılığı arasındaki ilişkinin, doğrusal olmayan konkav bir ilişki olduğunu göstermektedir. ${ }^{4}$ Pais ve Gama (2005) yapmış olduğu çalışmada teorik beklentinin aksine alacak tahsil süresi ve karllık arasında konveks bir ilişki olduğunu ortaya koysa da, bu çalışma sonuçları nakit döngüsü ve karlılık arasında konkav bir ilişki olduğunu ortaya koyan Banos- Caballero (2012) ve firmaların hedef bir alacak tahsil süresine sahip olduğunu ortaya koyan Garcia-Teruel ve Martinez-Solano (2010a) sonuçlarını destekler niteliktedir.

Model 1'den elde edilen sonuçlar (1. Sütun) ticari borç ödeme süresi değişkeninin $\boldsymbol{T} \boldsymbol{B}_{\boldsymbol{i}, t}$ katsayısının da pozitif (0.0003) bir katsayıya ve ticari borç ödeme süresinin karesi olarak ifade edilen $\boldsymbol{T} \boldsymbol{B}^{2}{ }_{i, t}$ değişkeninin ise negatif bir katsayıya (- (5.84e-07) sahiptir. Elde edilen sonuçlar istatistiki yönden anlamlıdır. Bu sonuçlar ticari borç ödeme süresi ve faaliyet karlılığı arasında da konkav bir ilişki bulunmakta olduğunu ortaya koymaktadır. ${ }^{5}$ Borç ödeme süresi ile ilgili olarak elde edilen bu sonuç Garcia-Teruel ve Martinez ve Solano (2010a)'nun ve Banos-Caballero vd (2012)'nun sonuçlarını destekler niteliktedir. Pais ve Gama (2005) teorik beklentinin aksine ticari borç ödeme süresi ve karlılık arasında teorik beklentinin tersi yönde sonuç bulmuşlardır.

Stoklar için elde edilen sonuçlara bakıldığında $S T_{i, t}$ değişkeni -0.0004 katsayısına sahiptir. Söz konusu değişkenin karesi olan $S T_{i, t}^{2}$ değişkeninin katsayısı $5.15 \mathrm{e}-$ 07 olarak tahmin edilmiştir. Sonuçlar istatistiki açıdan anlamlıdır. Elde edilen bu sonuç stokta bekleme süresi ve karlılık arasında doğrusal olmayan bir ilişsi olduğunu ortaya koymasına rağmen, ilişki beklenenin tersine konkav bir ilişki değildir. ${ }^{6}$ Elde edilen bu sonuç teorik beklentiye uygun olmasa da Pais ve Gama (2005) elde etmiş olduğu sonuç ile uyumludur.

Firmaya özgü kontrol değişkenlerinden sadece satı̧̧lardaki büyüme $B Y_{i, t}$ değişkeninin katsayısı istatistiki açıdan anlamlıdır ve söz konusu değişken karlılı̆̆ pozitif

\footnotetext{
${ }^{4}$ Alacak tahsil süresi için bulunan tepe noktası 129 gündür.

${ }^{5}$ Borç ödeme süresi için tepe noktası 229 gün olarak hesaplanmıştır.

${ }^{6}$ Buradaki minimum nokta 389 gün olarak hesaplanmıştır.
} 
yönde etkilemektedir. Çalışmada kullanılan makroekonomik değişkenlere ilişkin olarak elde edilen sonuçlar istatistiki açıdan anlamlı değildir.

Faiz ve vergi Öncesi Kar (KAR2) ile oluşturulan modele bakıldığında ise bir önceki dönem karlılık oranının bir sonraki dönem karlılığı üzerindeki etkisi pozitif olmasına rağmen bulunan sonuç istatistiki açıdan anlamlı olmadığı görülmektedir. Yine bu modelde de $\mathrm{AL}_{\mathrm{i}, \mathrm{t}} \mathrm{ile}$ ifade edilen alacak tahsil süresinin katsayısının pozitif ve anlamlı alacak tahsil süresinin karesi olan $\mathrm{AL}_{\mathrm{i}, \mathrm{t}}^{2}$ değişkenin katsayısı negatif ve anlamlıdır. Bu sonuç alacak tahsil süresi ve faiz ve vergi öncesi kar değişkeni arasında konkav bir ilişki olduğunu ifade etmektedir. ${ }^{7}$ Stoklar için elde edilen sonuç da faaliyet karı sonuçları ile uyumludur. ST $_{\mathrm{i}, \mathrm{t}}$ değişkeni negatif ve anlamlı, ST $^{2}{ }_{\mathrm{i}, \mathrm{t}}$ değişkenini ise pozitif ve anlamlı katsayıya sahiptir. ${ }^{8}$. Borç ödeme süresi için elde edilen sonuçlar ise istatistiki açıdan anlamlı değildir. Kontrol değişkenlerinden firma büyüklüğü ve büyüme değişkenlerindeki artış faiz ve vergi öncesi karı arttırmakta, kaldıraç oranındaki artış ise söz konusu karlılığı azaltmaktadır. Bulunan sonuçlar istatistiki açıdan anlamlıdır. Makroekonomik değişkenlerden sadece faiz oranı faiz ve vergi öncesi karı olumlu yönde etkilemektedir. Bu durum analiz edilen dönemde faiz oranlarındaki ortalama değişim oranının negatif olmasından yani faiz oranlarının düşüyor olmasından ileri geliyor olabilir.

Tablo 3. Karlılık ve İşletme Sermayesi Unsurları İlişkisi-Fark GMM Analizi Robust Sonuçları ${ }^{9}$

\begin{tabular}{|c|c|c|}
\hline Değişkenler & Faaliyet Karlılı̆g1 & $\begin{array}{c}\text { Faiz ve Vergi Öncesi } \\
\text { Karll11k }\end{array}$ \\
\hline$K A R 1_{1, i t-1}$ & $0.171^{*}$ & \\
\hline$K A R 1_{2 i t-1}$ & & 0.022 \\
\hline$A L_{\text {i,t }}$ & $0.001 * *$ & $0.002 * *$ \\
\hline$A L_{\text {i.t. }}^{2}$ & $-4.64 \mathrm{e}-06^{* *}$ & $-6.27 \mathrm{e}-06^{*}$ \\
\hline$S T_{i, t}$ & $-0.0004 * *$ & $-0.0004 * *$ \\
\hline$S T_{i, t}^{2}$ & $5.15 \mathrm{e}-07 * * *$ & $6.27 \mathrm{e}-07 * * *$ \\
\hline$T B_{i, t}$ & $0.0003 *$ & 0.00008 \\
\hline$T B^{2}$ it: & $-5.84 \mathrm{e}-07 * *$ & $-3.71 \mathrm{e} 07$ \\
\hline$F B_{i, t}$ & 0.020 & $0.057 * * *$ \\
\hline
\end{tabular}

\footnotetext{
${ }^{7}$ Tepe noktası 148 gün olarak hesaplanmıştır.

${ }^{8}$ Bu ilişkide bulunan minimum nokta 318 gündür.

${ }^{9}$ Sektör ortalamalarına göre düzeltilmiş verilerle yapılan analiz sonuçları yukarıda elde edilen sonuçları desteklemektedir. Varlık karlılığı (ROA) kullanılarak yapılan analiz sonuçlarına göre sadece alacak tahsil süresi ve söz konusu karlılık oranı arasında doğrusal olmayan konkav bir ilişki tespit edilmiştir. İstenildiği takdirde bu sonuçlar da yazar tarafindan temin edilebilir.
} 


\begin{tabular}{|c|c|c|}
\hline$B Y_{i, t}$ & $0.115^{* * *}$ & $0.106^{* * *}$ \\
\hline$K A L_{i, t}$ & -0.045 & $-0.169 * * *$ \\
\hline$D V_{\mathrm{i}}$ & -0.046 & -0.036 \\
\hline$F A \mathfrak{i} Z_{i}$ & 0.216 & $0.389 * * *$ \\
\hline$E N F_{\mathrm{i}}$ & -0.292 & -0.79 \\
\hline Sabit & -0.268 & $-0.68 * * *$ \\
\hline AR (1) P-Değeri & 0.0045 & 0.0002 \\
\hline AR (2) P- Değeri & 0.1577 & 0.4610 \\
\hline Gözlem Sayısı & 202 & 202 \\
\hline Firma Say1s1 & 25 & 25 \\
\hline
\end{tabular}

Çalışmada otokorelasyon olup olmadığının tespiti için yapılan testte, beklentiye uygun şekilde AR (1) tipi korelasyon tespit edilmiş ve AR(2) tipi korelasyonun olmadığ 1 sonucuna ulaşılmıştır.

\section{SONUÇ}

İşletme sermayesi yönetimi ve karlılık ilişkisi literatürde çokça araştırılmış olan bir konu olmasına rağmen, çalışmaların pek çoğu bu ilişkiyi doğrusal modellerle test etmeye çalışmıştır. Oysa ki işletme sermayesindeki artışın karlılık üzerindeki etkisi, başlangıçtaki işletme sermayesi düzeyine göre farklılık gösterebilir. Düşük düzeyde stoklara, alacaklara ya da ticari borçlara sahip firmalar için bu unsurlardaki bir artış karlılığı arttırırken, yüksek düzeyde işletme sermayesine sahip firmalar için bu unsurlardaki artış karlılığı azaltabilir.

Bu çalışma Borsa Istanbul'da 2005-2016 döneminde Kimya, Petrol, Kauçuk ve Plastik Ürünler sektöründe faaliyet gösteren firmaların verileri kullanılarak fark genelleştirilmiş momentler yöntemi ile (GMM) ile gerçekleştirilmiştir. Bu çalışmada elde edilen sonuçlara göre özellikle alacak tahsil süresi ve karlılık oranları arasında doğrusal olmayan (Konkav) bir ilişki bulunmaktadır. Bulunan ilişki analize tabi tutulan firmalar için optimal bir alacak tahsil süresinin olduğunu ortaya koymaktadır. Literatürde işletme sermayesi unsurları ve karlılık arasındaki ilişkiyi doğrusal olmayan modellerle test eden az sayıda çalışma bulunmaktadır. Çalışma sonuçları nakit döngüsü ve karlılık oranları arasında doğrusal olmayan ilişki olduğunu tespit eden Banos- Caballero vd. (2012) sonuçlarını destekler niteliktedir. Ayrıca kısmi düzeltme modeli kullanarak gerçekleştirmiş oldukları analizde Garcia-Teruel ve Martinez ve Solano (2010b) firmaların hedef bir alacak tahsil süresine sahip olduğunu ve bu hedeften saptıklarında hedefe tekrar yöneldiklerini ortaya koymuşlardır. Kullanılan modeller 
farklı olmasına rağmen, alacak tahsil süresi için optimal bir düzeyin olduğuna dair sonuçların olması, Garcia-Teruel ve Martinez ve Solano (2010b) çalışmasını desteklemektedir.

Stoklar için elde edilen sonuçlar ise beklentinin tersi yönde gerçekleşmiştir. Beklentinin aksine stok düzeyinin artması karlılık oranlarını belli bir stokta bekleme süresine kadar azaltmakta daha sonra ise arttırmaktadır. Bu beklenmeyen ilişki Pais ve Gama (2005)'nın sonuçları ile uyumludur. Minimum noktanın yüksek bir stokta bekleme süresinde gerçekleşmesi genel olarak firmalarda stokta bekleme süresi arttığında karlılığın azaldığı şeklinde yorumlanabilmektedir.

Faaliyet karının bağımlı değişken olarak kabul edildiği analiz sonuçlarına göre ticari borçlar bir noktaya kadar karlılığ 1 arttırmakta ancak bu noktanın üzerinde karlılığa zarar vermektedir. Burada da elde edilen sonuç ticari borç ödeme süresi ve karlılık ilişkisinin konkav bir ilişki olduğudur. Çalışma sonuçları nakit döngüsü ve karlılık arasında konkav bir ilişki olduğunu ortaya koyan Banos- Caballero vd. (2012)'nun sonuçlarını ve firmaların hedef bir borç ödeme süresi olduğunu ifade eden Garcia-Teruel ve Martinez-Solano (2010a) sonuçlarını destekler niteliktedir.

Çalışma sonuçları işletme sermayesi yönetimi ve karlılık ilişkininin analizinde ileride yapılacak olan çalışmalarda doğrusal olmayan modellerin kullanımının önemli olduğunu ortaya koymaktadır.

\section{KAYNAKLAR}

Akbulut, Ramazan (2011), “ IMKB’de İmalat Sektöründeki İşletmelerde İşletme Sermayesi Yönetiminin Karlılık Üzerine Etkisini Ölçmeye Yönelik Bir Araştırma”, İstanbul Üniversitesi İşletme Fakültesi Dergisi , 40(2), ss.195-206.

Akgüç, Öztin (1998), Finansal Yönetim, Avcıl Basım Yayı, İstanbul.

Aktas, Nihat- Croci, Ettore- Petmezas, Dimitris (2015),” Is Working Capital Management Value-Enhancing? Evidence from Firm Performance and Investments" Journal of Corporate Finance, 30, pp.98-113.

Arellano, Manuel -Bond, Stephen (1991), "Some Test of Specification for Panel Data: Monte Carlo Evidence and an Application to Employment Equations", Review of Economics Studies, 58, ss.277-297.

Aytürk, Yusuf-Yanık-Serhat (2015), “Çalışma Sermayesi Yönetimi Türkiye'deki KOBİ’lerde Karlılı̆̆ Nasıl Etkiler?” Muhasebe ve Finansman Dergisi, Ekim, 157-168.

Banos-Caballero, Sonia- Garcia-Teruel, Pedro J.- Martinez-Solano, Pedro (2012), “ How Does Working Capital Affect the Profitability of Spanish SMEs?" Small Business Economics, 39, pp. 517-529.

Brigham, Eugene F. - Houston Joel F. (2002), Fundamentals of Financial Management, US, South Western Thomson Learning. 
Chung, Kun-Jen (2010), “ The Viewpoint on "Optimal Inventory Policy with NonInstantaneous Receipt under Non-Instantaneous Receipt Under Trade Credit by Ouyang, Teng, Chuang and Chuang", Int. J. Production Economics, 124, pp. 293-298.

Coşkun, Ender -Kök, Dündar (2011), “Çalışma Sermayesi Politikalarının Karlılık Üzerine Etkisi: Dinamik Panel Uygulaması” Ege Akademik Bakış, 11, ss.75-85.

Çakır, Hafize M.- Küçükkaplan, İlhan (2012), “İşletme Sermayesi Unsurlarının Firma Değeri ve Karlılığı Üzerindeki Etkisinin İMKB'de İşlem Gören Üretim Firmalarında 2000 2009 Dönemi İçin Analizi”, Muhasebe ve Finansman Dergisi, Ocak, ss. 69-86.

Deloof, Marc (2003), “ Does Working Capital Management Affect Profitability of Belgian Firms?" Journal of Business, Finance and Accounting, 30, pp.573-587.

Deelof, Marc-Jegers, Marc (1996), "Trade Credit, Product Quality, and Intragroup Trade: Some European Evidence" Financial Management , 25 (3), Special Issue: European Corporate Finance , pp. 33-43

Emery, Gary, W. (1984), “ A Pure Financial Explanation for Trade Credit”, Journal of Financial and Qunatitative Analysis, 9: pp.271-285.

Emery, Gary, W. (1987), “ An Optimal Financial Response to Variable Demand”, Journal of Financial and Quantitative Analysis, 22 (2): pp. 209-225.

Garcia-Teruel,Pedro J. -Martinez-Solano, P. (2010a). " A Dynamic Perspective on the Determinants of Accounts Payable" Rev Quant Finan Acc, 34, pp. 439-457.

Garcia-Teruel,Pedro J. -Martinez-Solano, P. (2010b).” A Dynamic Approach to Accounts Receivable: A Study of Spanish SMEs", 16 (3), pp. 400-421.

Keskin, Rıdvan- Gökalp, Füsun (2016), “ Çalışma Sermayesi Yönetiminin Firma Karlılığ1 Üzerine Etkisi: Panel Veri Analizi”, Doğuş Üniversitesi Dergisi, 17 (1), ss. 15-25.

Nadiri, Mohammed, I. (1969). " The Determinants of Trade Credit in the US Total Manufacturing Sector", Econometrica, 37 (3), pp. 408-423.

Ouyang, L. Y.- Teng, J. T.- Chuang, K. W. - Chuang, B. R. (2005). "Optimal Inventory Policy with Noninstantaneous Receipt Under Trade Credit”. International Journal of Production Economics, 98, pp. 290-300.

Öz, Yaşar- Güngör, Bener (2007), “Çalışma Sermayesi Yönetiminin Firma Karlılığı Üzerine Etkisi: Imalat Sektörüne Yönelik Panel Veri Analizi”, Atatürk İktisadi ve İdari Bilimler Dergisi, 10(2), ss.1-14.

Pais, Maria A.- Gama, Paulo M. (2005) “Working Capital Management and SME'S Performance: Portuguese Evidence" International Journal of Managerial Finance, 11(3), pp. 341-358. 
Roodman, David (2009), “ How to Do Xtabond2: An Introduction to Difference and System Gmm in Stata" The Stata Journal, 9(1), pp. 86-136.

Ross, Stephen A., Westerfield Randolph W., Jeffrey, Jaffe, Jordan, Bradford D. (2008)“ Modersn Financial Management, McGrawHill, Boston, USA.

Singhania Monica- Sharma, Navnedu- Rohit, Yagnesh J. (2014,) "Working Capital Management and Profitability: Evidence from Indian Manufacturing Companies", Decision, 41, pp.327-337.

Şamiloğlu, Famil- Demirgüneş K. (2008), "Effect of Working Capital Management on Firm Profitability: Evidence from Turkey", The International Journal of Applied Economics and Finance, 2(1),ss. 44-50.

Tatoğlu, Ferda Yerdelen (2013), İleri Panel Veri Analizi, Beta Yayınları, İstanbul.

TCMB (2017), TCMB Sektör Bilançoları İstatistikleri (2014-2016), İstatistik Genel Müdürlüğü.

Vahid, Taghizadeh K.- Elham, Ghanavati- Mohsen, Akbari K.- Mohammedreza, Ebrati (2012), "Working Capital Management and Corporate Performance: Evidence from Iranian Companies", Procedia: Social and Behavioral Sciences” 65,pp. 1313-1318.

Weinraub, Herbert J.- Vissher, Sue (1998), “ Industry Practice Relating to Aggressive Conservative Working Capital Policies" Journal of Financial and Strategic Decisions, 11 (2), pp.11-18. 
